\title{
FORMATION AND DEVELOPMENT OF VALUABLE ORIENTATIONS OF STUDENTS IN THE EDUCATIONAL PROCESS OF HIGHER EDUCATION IN UKRAINE
}

The essence of the phenomenon of "value orientation", "formation of student value orientations" has been revealed $n$ the article. The "professional values" as an integrated multi-level education, the coordinate system and the corresponding regulations of the professional's specialist activity have been substantiated. It has been established that professional values of student youth include professional responsibility, the essence-content content of pedagogical work, its moral aspect, principles and professional relations. The functions of value orientations and peculiarities of their formation in the professional training of future specialists of higher education institution of Ukraine have been determined. The peculiarities of students' values $n$ higher education institutions have been revealed. The criteria (cognitive, motivational, activity, personal) and levels (low, average, sufficient and high) of professional-value orientations of students have been determined.

The model is developed and pedagogical conditions of formation and development of students'value orientations in the educational environment of the higher education institution have been substantiated: formation of positive motivation for the profession and necessity of ethical regulation of their own professional actions; updating of educational and methodological support and substantive content of future specialists' professional training (due to the development and implementation of the special course and enrichment of the content of professional disciplines with an axiological component); ensuring systematic and comprehensive self-assessment of professional activity, self-knowledge concerning the acquisition of groups of professional values.

It was established that the mechanism of formation of value orientations in students of higher education institution includes the stages: perception; response (subordinate, voluntary, satisfaction response); assimilation of professional values (acceptance of values, prevalence of professional values, conviction); organization of professional values (conceptualization of professional values, organization of a system of professional values); use of professional values (internalization of professional values, use of professional values in activities).

Keywords: values, value orientations, professional-value orientations of students, model of formation of value orientations, pedagogical conditions of formation of value orientations of students.

Formulation of the problem. Valuable orientation of students is one of the important components in the structure of the personality: they reveal the attitude towards the outside world and find their expression in the interests, needs, views, assessments, motives of social and professional activity. The formation of the system of values of young people, their transformation into value orientations are defined as the priority goals of the modern higher education, declared by the Laws of Ukraine "About Education" and "About Higher Education", the Decrees of the President of Ukraine "About the National Strategy for the Development of Education in Ukraine for 2012-2021", "About the Strategy of National-Patriotic Education of Children and Youth for 2016-2020": it has been stated that the important goals of educational practice are the formation of the personality through patriotic, legal, ecological education, participants in the educational process of moral values, social activity, civic attitude and responsibility, healthy lifestyle, ability to think freely and self-organize in modern conditions.

The analysis of psychological and pedagogical literature has shown that the problem of the formation of value orientations of students of higher education institutions, for which they are one of the most important elements in the structure of the professional image of the world, attention is almost not paid in the educational process of the university. In higher education, the formation of professional-value orientations of students is still fragmentary and, for the most part, is limited to studying subjects of the social and humanitarian cycle. Hence, it is erroneous to identify the concepts of values and value orientations; lack of understanding of the mechanisms of the transformation of values in the value orientation of the individual, not well-grounded methodology of diagnosing the level of formation of professional-value orientations of students. This situation slows the implementing of the axiological approach to the practice of students' professional training at the university.

The lack of thorough and systematic research on the problem of the formation of professional-value orientations for students of humanities is exacerbating the contradictions between: social needs in formation the value sphere of the personality of a future specialist and its underestimation in the preparation of students at the university; objectively high value-development potential of the educational environment of the university and practically insufficient level of formation of professional-value orientations of students; increased requirements for the professional-value orientations of the future specialist and the lack of a scientifically grounded methodology for the implementation of this process in a higher education institution.

The research obective is to theoretically substantiate the model and pedagogical conditions for the formation and development of student value orientations in the educational process of higher education institution. According to the obective, the goals of the study have been defined: 1) to reveal the essence of the concept of "formation of value orientations of students" on the basis of clarification of the content of key concepts of the study; to define functions of professional-value orientations and peculiarities of their formation in the training of future specialists in humanities; 2) to substantiate theoretically the model of the formation of value orientations of students in the educational process of higher education institution; 3 ) determine the pedagogical conditions for the formation of professional-value orientations of students of humanities.

Analysis of recent research and publications. The work of such psychologists as B. Ananiev, V. Volkova, O. Drobnitsky, G. Zaleski, A. Zdravomyslova are devoted to theoretical analysis of the problem of the formation of values and occupational-value orientations. Different aspects of the formation of value orientations of the individual are analyzed in the writings of the pedagogues: $\mathrm{E}$. Basin, V. Biruli, V. Dzyuba, N. Maksymchuk, L. Morozova, O. Naboki, L. Panchenko, O. Tsichotskaya, S. Shandruk, V. Shakhraya.

The axiological approach to the professional training of students, expressed in the orientation of vocational education to the formation of a system of universal human values and professional values that determine the attitude to the outside world, to themselves, their own activities, is disclosed in the scientific works of R. Artsyshevsky, I. Bekh, O. Braslavskaya, M. Yevtuha, I. Zyazyun, A. Mischenko, E. Pochinok, N. Tkacheva, A. Yaroshenko and others.

Research presentation. The period of study at an institution of higher education is extremely important in the formation of value orientations in student youth: firstly, in the 
personality the formation of professional competence is formed and the attitude towards the future profession is formed, and secondly, a revaluation of the values inherent in the personality prior to admission to a higher educational establishment and thirdly, the assimilation of new values takes place in the process of interaction with other representatives of the university community. It is necessary to emphasize the importance of higher educational institutions in the process of self-determination of young people and in the process of forming future specialists, since the university plays as a favorable environment not only for the development of professional skills of the student, but also for its development, because it is the embodiment of society in miniature. Thus, the system of values correlates with the concrete historical, socio-political, ideological conditions in which it forms in society as a whole and in each individual person.

Definitive analysis of the concept of "professional-value orientations of the individual" (B. Ananiev, I. Beh, I. Isaev, M. Kagan, O. Kaminska, E. Klimov, A. Leontiev, N. Mironova, L. Orshansky, E. Podolskaya, N. Schemigon, etc.) showed his complexity and connection with the concepts: "value", "professional value", "value orientation of the individual", etc.

The concept of "value orientation of the individual" should be regarded as accepted and understood by the personality of the values that determine his or her choice of a certain type of behavior, actions, way of life.

It was established that the value is subjective-objective, and the value orientation is subjective, and, therefore, the transition of values in value orientations is evidence of objectivization of the individual. Since value orientations are, firstly, a means of detecting the subjective attitude of the individual towards the outside world and, secondly, of the integral psychic neoplasms that provides the integrity of the consciousness, the emotional-sensory sphere and the behavior of the subject, then the value orientations on the basis personal orientation and value; direct educational-professional knowledge; contribute to the value selection of objects of cognition; stimulate both the realization of professional opportunities, and the implementation of the dissatisfied needs of the individual from self-development, self-realization.

Professional-value orientations of students of humanities are a stable system of personal and professional-conscious personality values that serve as benchmarks for professional activity, a motive for professional self-improvement and a regulator of professional-value position. It was found out that professional-value orientations of students of humanities contain a number of common features, described above, but are mediated by peculiarities of humanitarian professions, reflect the content and essence of professional activity, determine its purpose and means, regulate the behavior of the person in the activity.

It should be noted that the professional-value orientations of future specialists have the following functions: diagnostic-cognitive (establishing the real level of professional readiness and knowledge of the new in the context of professional activity), prognostic and motivational (prediction of future professional activity, its results and motivation of professional self-improvement), control-evaluating (control and evaluation of personal professional knowledge, skills and abilities), reflexive and regulatory (self-knowledge, regulation of professional-value position, self-regulation).

It is determined that formation of professional-value orientations of students of humanities is a multidimensional, purposeful and managed process of professional-value formation of the person, which is aimed at transformation of personal and professional values of students into profes- sional-value orientations in order to ensure the effective realization of socially competent and professional value-oriented their activities.

It is established that the peculiarities of formation of professional-value orientations of students of humanities in the educational process of the university are conditioned by: the need to take into account the specifics of the professional training of future specialists; the expediency of creating an educational university environment conducive to the development of the value sphere of the individual; the polyphasicity of this process; the presence of specific characteristic qualities and properties of a social group, as a student, and age characteristics of youth as a stage of personal development of a future specialist.

It is worth mentioning the need to determine the criteria for the formation of professional-value orientations of students, namely: 1) cognitive (consciously valued knowledge of professional knowledge, the essence-functional understanding of the concepts of "values", "value orientations of the individual", the presence of cognitive interest in future professional activities, 2 ) motivational (motivation of professional activity, motivation of activity and creativity in professional activity); 3) activity (availability of practical skills and abilities, creativity in professional activity, activity in professional activities); 4) personal (level of self-evaluation of personality and self-assessment of realization of life goals of student's personality; social and life values; values and value orientations; real structure of value orientations of the person; level of relation of "value" and "accessibility" in different spheres of life; level of organization and activity of the process the realization of life's vocations, the level of actualization $[2 ; 6]$.

To determine the level of formation of professional-value orientations of students of humanities, it has been developed and implemented a methodology for the diagnosis of formation of each criterion: 1) according to the cognitive criterion (analysis of students' progress, analysis of creative and control works, test of unfinished sentences, conversations and observations); 2) according to the motivational criterion (conversation, observation, questioning, diagnostics of the motivation of professional activity ( $\mathrm{K}$. Zemfir in the modification of A. Rean), analysis of creative works); 3) according to the activity criterion (observation, questioning, analysis of creative works, analysis of student behavior in a particular pedagogical situation, decision of exercises, expert assessments, methods for identifying the creative potential of a student's personality ( $\mathrm{N}$. Kirscheva, N. Ryabchikova)); 4) according to the personal criterion (interviews, questionnaires, observations, methods of self-assessment, self-assessment of the realization of the goals of life of the individual (M. Molochnikov), "life calling" (O. Motkov), study of the level of real harmony of integral indicators of the basic personality, determination of vital values personality (Musttest) (P. Ivanov, E. Kolobova), research of social values of the person, "value orientations" (M. Rokicha), diagnostics of the real structure of value orientations of the person (S. Bubnov), estimation of the level of the self-act ation (A. Shostroma by questionnaire) and individual self).

By the frequency and power of the manifestations of the determined indicators of each of the criteria, the levels of formation of students' professional and value orientations are characterized: low, average, sufficient and high.

Low level of formation of professional-value orientations is characteristic for students who possess basic professional knowledge, fragmentary understanding of the essence and functions of value concepts; they lack a cognitive interest in future professional activities; external motivation for professional activity prevails and there is no motivation for creative 
activity and activity in professional activity. These students are not aware of the role behavior in future professional activities, not having practical skills and skills, an initiative; are passive in interpersonal interaction; they lack the clarity in the hierarchy of values, in the formation of life goals and expressiveness of the position of life, in the harmony of the integral indicators of the basic personality; they are not ready for self-regulation and self-actualization.

The average level of formation of professional-value orientations is inherent in students who have sufficient professional knowledge, superficially possess valuable concepts, partly understanding their essence and functions; situationally expressed cognitive interest in the future profession; they are dominated by the external motivation of choosing a future profession over the internal. Such students are situationally aware of their personal role in future professional activities; have skills and abilities of future professional activity; are situationally active and creative; recognize the values of universal values, although individual values prevail. They are characterized by moderate realization of life goals, harmony of integral indicators of the basic personality and expression of a position of life, situational transformation of professional values into professional value orientations and elemental readiness for self-regulation and self-actualization.

Sufficient level of formation of professional-value orientations is fixed among students who possess high-quality professional knowledge, valuable concepts with elements of their creative interpretation, expressed cognitive interest in future professional activity, motivation of achievement and professional activity with even distribution of external and internal motivation, wide repertoire of professional role behaviors They have professional practical skills; are proactive, active and creative, confident in their own forces, including in future professional activities; Representation of value orientations at the terminal and instrumental levels; transform professional values into professional-value orientations; They are characterized by the sufficiency of the harmoniousness of integral indicators of the basic personality and readiness for self-regulation and self-actualization.

The high level of formation of professional-value orientations is characteristic for students with systemic and sound professional knowledge, conscious and valued possession of valuable concepts expressed by cognitive interest in the future profession; a pronounced internal motivation for academic, research, community-based and future professional activities. They are characterized by a multifaceted and conscious repertoire of professional roles, activity, responsibility, participation in student self-government, leadership, creativity; conscious choice of axiological landmarks, conscious perception of professional values and their transformation into professional value orientations; awareness of professional-value orientations as a motivator of professional activity and regulator of professional self-improvement; harmony of integral indicators of the basic personality and readiness for self-regulation and self-actualization.

It was researched that according to all the determined criteria of the formation of professional-value orientations students of the humanitarian specialties of the University are sufficient $(43.57 \%$ in the control group and $43.85 \%$ in the experimental group) and the average $(45.75 \%$ and $45.68 \%$ respectively). A significant part of students of humanities (5.23\% in the control group and $4.82 \%$ in the experimental group) has a low level of formation of professional-value orientations, while only $5.45 \%$ of the students of the control and $5.65 \%$ of the experimental group have a high level of formation professional-value orientations.
However, it should be noted that the better level of formation of professional-value orientations of students of humanitarian specialties according to activity and personal criteria, and it is is explained by the sensitivity of the youth age for personal formation in general and the value and professional-value sphere of the individual in particular, as well as the peculiarities of professional-value growth of students as a special social community. At the same time, it was found that students do not sufficiently determine the role and place of value orientations in professional development, which requires updating their motivation to develop a personal value sphere $[1 ; 3 ; 4]$.

It was found out that the indexes of the formation of professional-value orientations of students of humanities are the lowest according to the cognitive criterion: students have a superficial category of value categories: "value", "value orientation", "professional value", "professional-value orientation", functions of values, types values, etc., often identifying or substituting these concepts; reproductively reproduce knowledge, even without realizing their essence, use the basic methods of scientific knowledge. Thus, it should be noted that the organization of the educational process at the university is not connected with the formation of students of professional-value orientations.

The theoretically substantiated model of formation of professional-value orientations of students of humanitarian specialties of the University covers the following blocks: target (goal, tasks, methodological approaches, principles), content (training course "Professional-value orientations of future specialists", system of axiologically directed tasks of research work and practical training), technological (forms and methods, pedagogical conditions for the formation of professional-value orientations of students) and effective (criteria, indicators and forms of form vanosti vocational values and the result) (Fig. 1).

It should be noted that the pedagogical conditions for the formation of professional-value orientations of students of humanities in the educational process of the University are: the providingof the axiological orientation of the content of educational, cognitive, research work of students, their practical training; the use of interactive methods and forms of training aimed at developing professional-value orientations among students; effective management of the process of formation of professional-value orientations of students of humanities; formation of positive motivation to the profession and the need for ethical regulation of their own professional activities; ensuring systematic and integrated in the self-assessment of professional activity, self-knowledge about the acquisition of groups of professional values, namely: humanistic, deontological, communicative, competence, emotional-volitional, organizational.

In order to ensure the axiological orientation of the contents of the educational-cognitive, research work of students of the humanities, their practical training course "Professionalvalue orientations of future specialists" was developed and tested, which was implemented through lectures, practical and seminary classes, independent and individual work.

The educational process at the university is an important factor in the formation of students' professional and value orientations. And so, the main attention in the process of teaching the course and attracting students to research and practical training was emphasized on the need to transform the knowledge acquired in the belief, value, value orientation and practical activities.

Therefore, the goals of both academic activities and the research work of students, programs of passing them various types of practices was modified by axiological filling. These goals were distinguished by the creativity and unordinaryness of their solution. 


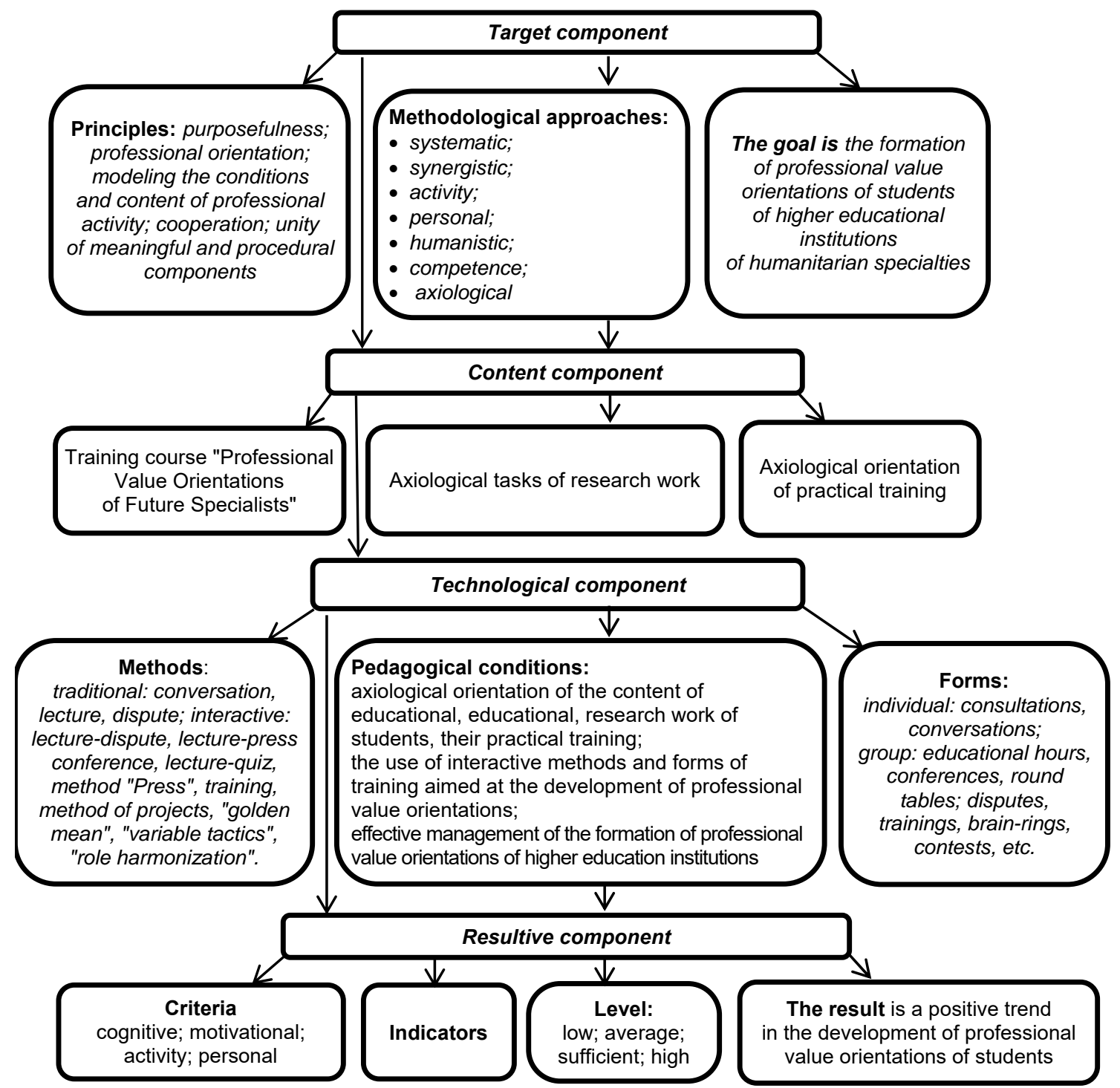

Fig 1. Model of formation of value orientations of students in the educational process of the institution of higher education

Problem lectures, lectures-visualizations, discussions, disputes, seminars, conferences, games, trainings, protection of projects were effective in the process of formation of professional-value orientations of students of humanitarian specialties; simulation of specific situations, case method, etc.

It was established that the mechanism of formation of professional values in students of higher education institution includes the following stages: 1) stage of perception (awareness, readiness for perception, selective attention to perception); 2) response phase (subordinated response, voluntary response, satisfaction response); 3) the stage of assimilation of professional values (acceptance of professional values, prevalence of professional values, conviction); 4) the stage of the organization of professional values (conceptualization of professional values, organization of a system of professional values); 5) the stage of use of professional values (internalization of professional values, the use of professional values in activities).

For the effective management of the process of formation of professional-value orientations of students of humanities, a special role belongs to the personality of the teacher as a professionally competent personality with the formed professional-value orientations. It is the purposeful activity of the teacher who creates a value-oriented educational environment at the university, taking into account the peculiarities of the professional training of future specialists, their personal traits, and the needs of social development, prompting students not only to memorize information, but also to comprehend it, make certain conclusions, generalizations, express their opinion, develop a position, strive for professional self-knowledge, self-improvement, self-education and self-education.

Conclusions. Summing up, it should be noted that the value orientations of the individual are defined as accepted and understood values that determine his or her choice of certain types of behavior, way of life. It is proved that in the structure of personality values orientations serve as the foundation on which the line of professional behavior is constructed. At the stage of the primary choice of the profession, professional values that are determined by the person as the most significant are beginning to form. In the process of professional development, values are checked, supplemented, gaining ever greater personal significance, and the person identifies himself or herself as a representative of the profession.

The conducted research does not include all research aspects of the problem. Further analysis and study need aspects of the application of new interactive technologies in the educational process of the university to form the value sphere of future professionals. 
References

1. Artimonova T. Osnovni dukhovni priorytety students'koyi molodi: napryamy transformatsiy / T. Artimonova // Vyshcha shkola Ukrayiny. 2008. № 1. S. 72-75.

2. Bekh I. D. Vykhovannia osobystosti: [navch. posibnyk] / I.D.Bekh. Kyiv.: Lybid', 2008. - $848 \mathrm{~s}$.

3. Hordieieva K. S. Profesiini tsinnosti $v$ systemi sotsial'no-pedahohichnoi roboty: psykholohichnyi aspekt / K. S. Hordieieva // Humanizatsiia navchal'novykhovnoho protsesu: zbirnyk naukovykh prats' / [za zah. red. prof. V. I. Sypchenka].- Slov'ians'k: DDPU, 2014. - Vypusk LXVIII. - Ch. I. - S. 182-188.

4. Entsyklopediia osvity [entsyklopediia ] / V.H.Kremen'. - Kyiv: Yurinkom Inter, 2008. - $1040 \mathrm{~s}$

5. Etyka: [navch. posibnyk] / V.O.Lozovoi, M.I.Panov, O.A.Stasevs'ka ta in. K.: Yurinkom Inter, 2002. - 224 s. - S. 103

6. Zhelanova V.V. Teoretyko-metodolohichni aspekty problemy tsinnostey osobystosti / V.V. Zhelanova, A.V. Petsanova // Visnyk Luhans'koho natsional'noho pedahohichnoho universytetu im. T.Shevchenka (pedahohichni nauky). 2008. № 7. S. 114-119.

7. Kalashnikova L.U. Umovy formuvannia sotsial'noi pozytsii studenta L.U.Kalashnikova // Pedahohika ta psykholohiia. 2014. - Vyp. 45. - S. 125-134.

8. Solovei M.I., Kudina V.V., Spitsyn le.S. Profesiino-pedahohichna pidhotovka maibutn'oho vchytelia $v$ kredytno-modul'nii systemi orhanizatsii navchannia: [navchal'nyi posibnyk] / M.I.Solovei, V.V.Kudina, le.S.Spitsyn. Kyiv: Lenvit, 2013. - 414 s. - S.148

9. Sukhomlyns'ka O. V. Tsinnosti u vykhovanni molodi ta ditey: stan rozroblennya problemy. Pedahohika i psykholohiya. 1997. № 1. S. 105-111.

10. Tsinnosti osvity i vykhovannia: [navch. posibnyk] / O.V.Sukhomlynska. Kyiv, 1997.
Список використаних джерел

1. Артімонова Т. Основні духовні пріоритети студентської молоді: напрями трансформацій / Т. Артімонова // Вища школа України. 2008. № 1. C. $72-75$

2. Бех І. Д. Виховання особистості: [навч. посібник] / І.Д.Бех. - К.: Либідь, 2008. -848 с.

3. Гордєєва К. С. Професійні цінності в системі соціально-педагогічної роботи: психологічний аспект / К.С. Гордєєва // Гуманізація навчальновиховного процесу: збірник наукових праць / [за заг. ред. проф. В. І. Сипченка]. - Слов'янськ: ДДПУ, 2014. - Випуск LXVIII. - Ч. I. - С. 182-188.

4. Енциклопедія освіти [енциклопедія ] / В.Г. Кремень. - К.: Юрінком Інтер, 2008. - 1040

5. Етика: [навч. посібник] / В.О. Лозовой, М.І. Панов, О.А. Стасевська та ін. - К.: Юрінком Інтер, 2002. - 224 с. - С. 103.

6. Желанова В.В. Теоретико-методологічні аспекти проблеми цінностей особистості / В.В. Желанова, А.В. Пецанова // Вісник Луганського національного педагогічного університету ім. Т. Шевченка (педагогічні науки). - 2008. - № 7. - С. 114-119.

7. Калашнікова Л.Ю. Умови формування соціальної позиції студента Л.Ю. Калашнікова // Педагогіка та психопогія. 2014 - Вип. 45. - С. 125-134.

8. Соловей М.І., Кудіна В.В., Спіцин Є.С. Професійно-педагогічна підготовка майбутнього вчителя в кредитно-модульній системі організації навчання: [навчальний посібник] / М.І. Соловей, В.В. Кудіна, Є.С. Спіцин. - К.: Ленвіт, 2013. - 414 с. - C. 148.

9. Сухомпинська О. В. Цінності у вихованні молоді та дітей: стан розроблення проблеми. Педагогіка і психологія. - 1997. - № 1. - С. 105-111.

10. Цінності освіти та виховання: наук.-метод. зб. / За заг. ред. Сухомлинської О.В. - К., 1997. - 224 с.

Надійшла до редколегії 12.05.19

Л. Левицька, канд. пед. наук, доц.

Н. Постоюк, канд. пед. наук, доц.

Київський національний університет імені Тараса Шевченка, Київ, Україна

\section{ФОРМУВАННЯ ТА РОЗВИТОК ЦІННІСНИХ ОРІЄНТАЦІЙ СТУДЕНТІВ ЗАКЛАДУ ВИЩОЇ ОСВІТИ УКРАЇНИ}

Розкрито сутність феномену "ціннісні орієнтації", "формування ціннісних орієнтацій студентів". Обґрунтовано "професійні цінності" як комплексне багаторівневе утворення, систему координат і відповідних регулятивів процесу професійної діяльності фахівця. Встановлено, що професійні цінності студентської молоді уособлюють у собі професійну відповідальність, сутніснозмістовне насичення педагогічної роботи, їі моральний аспект, принципи та професійні стосунки. Визначено фуункиї ціннісних орієнтацій та особливості їх формування у професійній підготовці майбутніх фахівців закладу вищої освіти України. З'ясовано особливості цінностей студентської молоді у закладах вищої освіти. Визначено критерії (когнітивний, мотиваційний, діяльнісний, особистісний) та рівні (низький, середній, достатній і високий) сформованості професійно-ціннісних орієнтацій студентів.

Розроблено модель та обґрунтовано педагогічні умови формування та розвитку ціннісних орієнтацій студентів в освітньому середовищі закладу вищої освіти: формування позитивної мотивації до професії та необхідності етичної регламентації власних професійних дій; оновлення навчально-методичного забезпечення та сутнісно-змістовного насичення фахової підготовки майбутніх фахівців (за рахунок розробки та впровадження спецкурсу та збагачення змісту фрахових дисциплін аксіологічним компонентом); забезпечення системності та комплексності в самооцінці професійної діяльності, самопізнанні щодо набуття груп професійних цінностей.

Встановлено, що механізм формування ціннісних орієнтацій у студентської молоді закладу вищої освіти охоплює етапи: сприйняття; реагування (підпорядковане, добровільне, задоволення від реагування); засвоєння професійних цінностей (прийняття цінностей, превалювання професійних цінностей, переконаність); організації професійних цінностей (концептуалізація професійних цінностей, організація системи професійних цінностей); використання професійних цінностей (інтеріоризація професійних цінностей, використання професійних цінностей у діяльності).

Ключові слова: цінності, ціннісні орієнтації, професійно-ціннісні орієнтації студентів, модель формування ціннісних орієнтацій, педагогічні умови формування ціннісних орієнтацій студентів.

UDC 378

I. Mariuts, PhD, Assistant Professor, O. Derkach, PhD student Taras Shevchenko National University of Kyiv, Kyiv, Ukraine

\section{QUALITY ASSURANCE OF UNIVERSITY EDUCATION IN EU COUNTRIES: ROMANIAN AND POLISH EXPERIENCE}

The article presents an analysis of external and internal assessment of the quality of higher education of Eastern European countries experience, namely Poland and Romania. These countries are close to Ukraine not only geographically, but also have a common socio-historical background. In particular, we consider it promising to introduce experience of these countries, since they have recently been successfully integrated into the European Higher Education Area, and Ukraine is still confidently following this path. The article presents the external quality assurance structure of higher education on the example of Romania, namely the organization, mission, tasks, activities of the Romanian Agency for Quality Assurance of Higher Education (ARACIS), is extremely relevant in the period of Ukrainian Agency for Quality Assurance of Higher Education formation. Concerning the assurance of internal quality of education, the article presents experience of Poland - analyzes the requirements for internal quality of education, standards, the activities of Polish Accreditation Commission.

Keywords: The European Higher Education, quality of higher education, Bologna Declaration, Poland State Accreditation Commission, Romanian Agency for Quality Assurance in Higher Education, Internal quality assurance of education, External quality assurance of education.

Formulation of the problem. The most important direction of the Bologna Declaration and corresponding tasks, implementation of which guarantees the reformation process of university education is to ensure the quality of education and control over it. This is due to globalization of all spheres of life of individual particularly and society in general, in conditions of civilizational tendencies of the modern world, requires the higher education to provide young people the 